\title{
Universiteit
}

Leiden

The Netherlands

\section{The political roots of domestic environmental sabotage}

Farrer, B.; Klein, G.R.

\section{Citation}

Farrer, B., \& Klein, G. R. (2016). The political roots of domestic environmental sabotage. Journal Of Elections, Public Opinion And Parties, 27(2), 133-155. doi:10.1080/17457289.2016.1247846

Version: $\quad$ Publisher's Version

License: $\quad$ Leiden University Non-exclusive license

Downloaded from: https://hdl.handle.net/1887/3238775

Note: To cite this publication please use the final published version (if applicable). 


\section{The political roots of domestic environmental sabotage}

\section{Benjamin Farrer \& Graig R. Klein}

To cite this article: Benjamin Farrer \& Graig R. Klein (2017) The political roots of domestic environmental sabotage, Journal of Elections, Public Opinion and Parties, 27:2, 133-155, DOI: 10.1080/17457289.2016.1247846

To link to this article: https://doi.org/10.1080/17457289.2016.1247846

\section{Published online: 25 Oct 2016.}

Submit your article to this journal $\pi$

山ll Article views: 274

Q View related articles ๘

View Crossmark data $\nearrow$ 


\title{
The political roots of domestic environmental sabotage
}

\author{
Benjamin Farrer ${ }^{\mathrm{a}}$ (D) and Graig R. Klein ${ }^{\mathrm{b}}$ \\ ${ }^{\mathrm{a} D}$ Department of Environmental Studies, Knox College, Galesburg, IL, USA; ${ }^{\mathrm{b}}$ Department of \\ Professional Security Studies, New Jersey City University, Jersey City, NJ, USA
}

\begin{abstract}
In this paper, we demonstrate that when environmentalist niche parties compete in a given constituency over a number of elections, but continually fail to win seats, then environmental sabotage becomes more frequent in that constituency. When mainstream tactics fail, radical tactics are used more frequently. Using a new data-set on the success rates of all Green Party candidates in US states, we show that environmental sabotage occurs more often when Green Party candidates fail to win even minor offices. This is true even when we control for other political expressions of environmentalism, such as interest group activity, and when we define 'success' through votes not seats. We discuss the implications of this for environmental politics, for social movements and democracy, and for political violence in the US.
\end{abstract}

\section{Introduction $^{1}$}

In this paper, we explain how frustration with the democratic process can lead to an increase in the frequency of political violence. We use the example of the environmental movement in the US, arguing that when radical environmentalists believe that mainstream environmentalists have been unable to make a difference through democratic politics, those radical environmentalists are increasingly likely to engage in environmental sabotage.

We argue that environmental sabotage is often motivated by the failure of other political expressions of environmentalism. Although most mainstream environmentalists would never consider sabotage, some radical environmentalists would, if mainstream political tactics have failed. We look at how two mainstream political tactics - electing Green Party candidates, and contributing to the campaigns of environmental candidates - influence the decision to engage in environmental sabotage. We argue that radical environmentalists see these tactics like a barometer. If the Green Party runs unsuccessful

CONTACT Benjamin Farrer benjaminfarrer@gmail.com

${ }^{1}$ The authors gratefully acknowledge the useful comments of the Binghamton Comparative Politics workshop, the editor, and the anonymous reviewers. They also acknowledge helpful discussions with Jodi Dean, Alex DiStefano, Michael Flynn, and Josh Zingher.

(c) 2016 Elections, Public Opinion \& Parties 
campaign after unsuccessful campaign, then frustration with democratic channels builds, and some radical environmentalists will turn to sabotage. Similarly, if mainstream environmental interest groups support candidates who prove to be unsuccessful, at election after election, then this too increases the frequency of sabotage.

Environmental sabotage became a national issue in the US in the 1980s and has persisted since. Common examples include spiking trees, releasing animals from captivity, or the arson of commercial and academic buildings. FBI Congressional testimony in the early 2000 s claimed that these incidents, taken together, were the most dangerous type of domestic terrorism. We explain the circumstances, particularly the political circumstances, which give rise to environmental sabotage. This paper proceeds as follows. First, we introduce the idea of environmental sabotage and review the recent literature on radical environmentalism. Second, we discuss our main causal mechanism. Third, we introduce a new data-set including measures of mainstream and radical tactics. We then move to our analysis, and find a strong positive correlation between the failure of mainstream tactics and the frequency of radical tactics. The fourth and final section concludes.

\section{Defining environmental sabotage}

We begin by defining environmental sabotage, because there is considerable debate over whether "environmental sabotage" or "environmental terrorism" is the more appropriate label for the same universe of events (Amster 2006; Hirsch-Hoefler and Mudde 2014; Marris 2006; Pellow 2014; Vanderheiden 2005; Varriale Carson, Lafree, and Dugan 2012). Hirsch-Hoefler and Mudde (2014) look at the incidents of threats and violence around the world attributed to the environmental movement, and find that most incidents are made up of vandalism and arson, with $10 \%$ of these incidents including threatening notes promising further unspecified violence against the targets. The authors argue that only this $10 \%$ fit the definition of terrorism, and the other incidents are better labeled as sabotage. However, the FBI tends to define all of these incidents as terrorism (Kuipers 2009), and some academics have defined terrorism broadly enough to include all these incidents. For example, Tilly (2004) defines terrorism as a strategy of "asymmetrical deployment of threats and violence against enemies" (5).

In this paper, the incidents included are those coded by the Global Terrorism Database (GTD): "the threatened or actual use of illegal force and violence by a non-state actor to attain a political, economic, religious, or social goal through fear, coercion, or intimidation" (START 2013). Since we only use GTD events perpetrated by environmentalists, however, we refer to these incidents as sabotage rather than terrorism. The argument against labeling sabotage as terrorism is twofold. First, there are civil rights consequences 
(Amster 2006) to the creeping expansion of the definition of terrorism to include even incidents that specifically avoid causing harm to living beings. ${ }^{2}$ Second, environmental saboteurs tend to target industrial or commercial activities that do significant harm to living things, yet those industrial/commercial activities are not widely seen as violent, let alone as "terrorist", despite the harm they do, which some environmentalists argue constitutes a double-standard (List 1993). Although addressing these arguments is not our primary focus, we believe that it is inappropriate to use "terrorism" in our paper, since our empirical universe consists of GTD coded incidents, only some of which contain all of the ingredients necessary for an academic consensus on classifying the incident as terrorism (HirschHoefler and Mudde 2014). Also, as stated, we only examine GTD incidents with clear environmental motivations. This classification process is usually straightforward because the perpetrators publicly take responsibility, and do so in a manner that clearly articulates their environmental motives. Importantly, the environmental goals self-reported by these radical saboteurs are similar to the goals reported by conventional environmentalists. In the next section, we provide more evidence for this similarity, and discuss how this influences substitution.

\section{From ballots to bullets?}

In this section, we discuss how radical environmentalists choose to commit sabotage based on the failure of mainstream environmentalists to achieve policy influence. The first step in demonstrating that these tactics have a substitutable rather than a complementary relationship is to demonstrate they strive to achieve the same goals (Farrer 2014; Lawson and Merkl 1988; Rootes 2013; Van der Heijden 1999; Weinberg, Pedazhur, and Perliger 2009). Of course, the goals of these social movement organizations (SMOs) are not exactly identical - the Green Party platform does not perfectly mirror what radical groups such as the Earth Liberation Front (ELF) and Animal Liberation Front (ALF) stand for - but the organizations are marked by important similarities (Hawkins 2006; List 1993). Doherty (2002) argues that Green parties, environmental interest groups, and environmental direct action groups, are all founded on the same ideology. There is a parallel between the environmentalism that motivates the Green Party to push for public transportation (Lees 2000; Meyer and Ely 1998; O'Neill 1997), and the ELF to commit arson against car dealerships (Hirsch-Hoefler and Mudde 2014; Marris 2006; Pellow 2014). To take another example, the Green Party advocates sustainable housing and regulation to restrict unsustainable housing (Lucas 2015),

\footnotetext{
${ }^{2}$ We revisit this in our conclusion, where we discuss possible generalizations of our argument to other forms of political violence whose perpetrators do not share this commitment.
} 
whereas the ELF burns down new luxury housing developments (Karasick 2009; List 1993). They target the same social problems, but target them in different ways (Doherty 2002; Hawkins 2006; List 1993). Evidence for this can be found from legal sources, from interviews, from the published work of environmentalists, and from academic research. In the trials following environmental sabotage incidents (Amster 2006; Deshpande and Ernst 2012; Kuipers 2009; List 1993), the perpetrators have frequently articulated environmental goals which are not dis-similar from the goals of mainstream environmentalists. This comports with other sources examining the decision-making of radical environmentalists. For example, Varriale Carson, Lafree, and Dugan (2012) conduct anonymous interviews with activists who are associated with radical environmentalism. The authors conclude that the desire for policy influence is an important motivating factor. Similarly, Joosse (2007) discusses how the ELF and ALF routinely send communiqués following their actions, and the vast majority give the motivating reason as preventing a specific harm, which is the same goal that motivates mainstream environmentalists (Kraft 2011).

This conclusion is reinforced by an extensive literature on competition between contentious SMOs. This research claims that if the political opportunity structure restricts Green Party successes, then SMOs working through democratic channels will be less able to compete for movement resources, and fringe SMOs advocating sabotage will be more competitive (Gamson 1975; McAdam, McCarthy, and Zald 1996; McAdam, Tarrow, and Tilly 2001; McCarthy and Zald 1977; Tarrow 1989; Tilly 2004). Because the policy goals of radical and mainstream environmentalists are similar enough, potential environmental saboteurs - and potential support networks and accomplices - use the successes and failures of the Green Party as a barometer to gauge the necessity for them to step outside the system, or whether change is possible within the system. ${ }^{3}$ If frustration with legal tactics rises, radical environmentalists will see the turn to illegal tactics as more legitimate. ${ }^{4}$

The electoral process allocates de jure power over policy decision-making, but when frustration mounts following a series of unsuccessful campaigns, some activists' pursue de facto power and influence through alternative politicking (Acemoglu and Robinson 2006, 2008; Dunnning 2011). Environmental activists typically extol legal and legitimate methods of influencing policies (Dryzek et al. 2003; Hawkins 2006; Varriale Carson, Lafree, and Dugan 2012), but - similar to how some activists radicalize when governments ignore

\footnotetext{
${ }^{3}$ Note that any dissimilarity between the Green Party platform and the platform of radical environmentalists only works against our empirical test. If the Green Party is more moderate than these groups, then ALF, EF!, and ELF members would be less likely to feel frustrated with the failure of Green Party campaigns, and so we would be less likely to find results.

${ }^{4}$ There is considerable evidence from the psychology of radical activists that they will turn to other tactics rather than give up completely (Farrer 2016; Kuipers 2009; List 1993).
} 
protests and the associated demands (Bishara 2015; McAdam, Tarrow, and Tilly 2001; Tarrow 1989) - the inability of the Green Party to achieve electoral success signals, for some activists, the status quo institutional apathy for environmental concerns and spurs radicalization. Individuals, particularly activists already engaged in a collective effort, are motivated to act when political policies and outcomes are perceived as unjust and inflexible (Bishara 2015); hence, when the Green Party repeatedly fails to win elections, radical environmentalism increases. We do not argue that this leads to all mainstream environmentalists becoming radical overnight and engaging in sabotage sabotage is, after all, a relatively rare event. Radicalization is a process that follows multiple pathways (Borum 2011). Activists are not radicalized by a single decision or event; rather, a sequence of events gradually encourages radicalization (Borum 2011; Horgan 2005; Silke 2008). There are always extremist preferences in society, but these preferences typically reside in the "tails" of a distribution of public opinion (Lake 2002). When environmentalists in the "tails" of society attempt to influence policy through the legitimate method of voting for the Green Party, but fail to win office, some of these individuals "up the ante" and accept the risks of environmental sabotage because it now seems more legitimate (Silke 2008). ${ }^{5}$ Pre-existing radical environmentalists become increasingly galvanized as they start to see their preferred tactics as increasingly legitimate (Enders and Sandler 1993). They also find it easier to recruit accomplices, as new radical environmentalists are encouraged to adopt extremist tactics when legal political outlets are deemed insufficient (Abrahms 2008; Aksoy and Carter 2014; Koopmans 1996; Weinberg, Pedazhur, and Perliger 2009).

Radical environmentalist discourse provides frequent evidence of this frustration-to-mobilization dynamic. For example, consider the following quote from Howie Wilkie, co-founder of radical environmental group Earth First!: "We played the game, we played the rules. We were moderate, reasonable, and professional. We had data, statistics, and maps. And we got $f^{* * * * *}$. That's when I started thinking 'Something's missing here. Something isn't working'" (Pellow 2014, 33). To give another example, consider this exchange between Dave Foreman, a founding member of Earth First!, and Eugene Hargrove, editor of Environmental Ethics, in 1982. Foreman describes how electoral frustration led directly to environmental sabotage:

Some of us began to feel, even before Reagan's election - it was time for a new joker in the deck: a militant, uncompromising group unafraid to say what

\footnotetext{
${ }^{5}$ This process is not unique to the environmental movement in the US; segments of the Irish Catholic population in Northern Ireland in the 1960s continually rallied around extremist tactics in response to insufficient political representation (McAllister 2004; Silke 2008). The leaderless resistance structure of some of the most prominent environmentalist organizations provides ample opportunity for frustrated activists to "self-radicalize" in this way, as the ELF encourages prospective supporters to organize their own cells rather than try to join existing ones (Leader and Probst 2003).
} 
needed to be said or to back it up with stronger actions than the established organizations were willing to take. (Dave Foreman, quoted in List 1993, 187)

to which Hargrove responds with a different perspective. His statement explicitly draws a connection between the activities of the Green Party and of environmental saboteurs. If the latter were more successful, there would be no need for the former:

While I can understand the frustration of the nonleaders of the nonorganization that so little was accomplished by environmentalist administrators during the Carter administration (the reason Earth First! was started), there are still legal and moral alternatives which could be pursued. An environmentalist political party like the Green Party in Germany, for instance, might provide the support that environmentalist administrators need to accomplish their goals - without the legal and moral difficulties Earth First!ers may face in the future. (Eugene Hargrove, quoted in List 1993, 254-255)

If legal mainstream tactics have a good record of success, then radical environmentalism will decline. Potential accomplices will be less motivated to step outside the system, and potential support networks will be harder to mobilize (Gamson 1975; Gruenewald, Allison-Gruenewald, and Klein 2015; Hawkins 2006; McAllister 2004; Weyler 2004).

The Green Party in the US has been active since 1984, and the various state parties came together in 1996, with a single national party founded in 2001. Ralph Nader gained considerable attention during his Presidential run on the Green Party ticket in 2000, but Green Party candidates have won hundreds of local offices throughout the US. However, they have never won a federal race, and though they are the fourth-largest party by membership, their electoral record is mixed (Hawkins 2006). As we discuss in the empirical section, in some states the Green Party has fielded many successful candidates, but in other states, they have consistently competed in elections, but have made minimal headway. It is that latter category of state that we argue will experience more environmental sabotage. ${ }^{6}$

The electoral results of the Green Party are not the only measure we use for whether legal mainstream tactics have been successful. Environmentalists might also share goals with candidates from other political parties. Many important pieces of environmental legislation in the US have been passed by Democrats and Republicans (Kraft 2011), and given the majoritarian electoral system in the US, environmentalists might look past the Green Party, and towards the influence of interest groups on these major parties, as a better barometer of whether mainstream environmental tactics are working (Farrer 2014; Meguid 2008). That is, if mainstream environmental interest

\footnotetext{
${ }^{6}$ We also leave until the empirical section a discussion of the states where no Green Party candidates have run. In brief, "frustration with mainstream tactics" cannot exist where those tactics have not yet been tried, and so do not expect that these states will experience more frequent sabotage.
} 
groups devote significant financial resources to the campaign of a particular candidate, then it suggests a similarity in ideological goals (Green et al. 2015; Kollman 1997). If these candidates fail to win their elections, then there is the potential for frustration to build. This causal pathway is more circuitous than our main hypothesis regarding Green Party successes or failures, but given the majoritarian electoral system in the US, it is important to test. If we find the same results for this alternative measure of "failure of mainstream tactics", then this lends further support to our argument.

A potential critique of this mechanism is that radical individuals are relatively alienated from mainstream politics and so will act regardless of the electoral context. However, environmental saboteurs rely on their support networks, which are often made up of more mainstream environmentalists (Enders and Sandler 1993; List 1993; Scarce 2006; Tilly 2004; Weyler 2004). For example, Kuipers (2009) describes how ALF activist Rod Coronado worked with many accomplices who required some persuasion in order to engage in criminal activities. This act of persuasion is much more difficult if potential accomplices believe that less risky tactics for policy influence might be at least as effective (Blazak 2001). A second potential critique of this mechanism is that causality may run in the other direction. That is, the use of illegal tactics is what causes the failure of legal tactics: a burgeoning mainstream movement may be damaged by the publicity surrounding its radical component (List 1993). We deal with this possibility in more detail in our empirical section, but for now we note that previous studies have found only limited support for this backlash effect. For example, Basque separatists and Irish unionists both continued to attract electoral support even as linked organizations pursued armed resistance (Weinberg, Pedazhur, and Perliger 2009).

In summary, we claim that the decision to employ violent tactics reflects the inability to affect environmental legislation through alternative bargaining processes. Just as "the placid poor get nothing, but the turbulent poor sometimes get something" (Fox Piven and Cloward 1971, 38), when conventional political environmentalists get nothing through continual electoral failure, the appeal of environmental sabotage, that could sometimes get something, increases. This leads to our main hypothesis.

Hypothesis 1: The frequency of environmental sabotage increases when the Green party has an extensive history of unsuccessful campaigns.

\section{Empirical test}

In this section, we describe the process of testing $\mathrm{H} 1$. To begin with our dependent variable, GTD records 155 incidents perpetrated by environmental groups in the US between 1985 and 2005. GTD assigns responsibility for 
incidents using publically available sources, usually electronic news archives, academic journals, and legal documents. The vast majority of these incidents were planned by the ALF or ELF, who were responsible for 60 and 58 incidents, respectively. Our dependent variable is the count, per U.S. state-year, of Environmental Sabotage. This count treats each incident as the same, which does not account for the differences between minor vandalism and large-scale arson. However, it is important to note that the count is truncated by not including the lowest-level incidents: the most minor incidents are not counted by GTD and so the remaining count is at least somewhat more comparable. Furthermore, following Gruenewald, Allison-Gruenewald, and Klein (2015) and Deshpande and Ernst (2012), we believe that a different process, such as the availability of targets, may cause variation in the severity of an incident, and so we continue with the count formulation for present purposes. California (38), Oregon (19), Arizona (15), Washington (14), and Michigan (12) have the highest frequency of events. Attacks have become increasingly common since 1985. From 1985-1989, there were 14 incidents. During the 1990s, there were 64 environmental sabotage incidents. And, from 2000 to 2005, GTD records 81 environmental sabotage incidents.

We use a zero-inflated negative binomial model to predict our dependent variable (Cameron and Trivedi 1998). We make this choice because we believe that two separate processes influence our dependent variable. The first is the process that our theory deals with: as environmental activists grow frustrated with elections they turn to environmental sabotage instead. However, our dependent variable also captures some states where there is a small environmental movement, and so the absence of Green Party officeholders does not indicate a failed electoral campaign, it instead indicates that no meaningful campaigns were mounted. Therefore, the overall presence or absence of an environmental movement is the second process being captured by our dependent variable. This second process serves to "inflate" the count of zeros in our dependent variable, and so the zero-inflated negative binomial model is the appropriate estimation.

The first right-hand side variable we use to estimate this model is the last five years of Green Party electoral history in the state. The Green Party of the USA maintains a database of every candidate, the office they ran for, and whether they won or lost. Table 1 presents the total number of local-level offices, state-level offices, and federal-level offices that Green Party candidates ran for, and how many they won. The data cover a 21-year period from 1985 to 2005.

The data in Table 1 show significant variation, with hundreds of races run (and hundreds won) at the local level in California, but over the same period the Green Party never ran even one candidate at any level in several states: Kansas, Nevada, Oklahoma, South Carolina, South Dakota, or West Virginia. Also, despite running candidates in 276 federal races, the Green Party had 
Table 1. Green party offices sought and offices won, by jurisdiction and state, 1985-2005.

\begin{tabular}{|c|c|c|c|c|c|}
\hline & Local races & Local victories & State races & State victories & Federal races \\
\hline Alabama & 1 & 0 & 0 & 0 & 0 \\
\hline Alaska & 19 & 7 & 23 & 0 & 13 \\
\hline Arizona & 12 & 6 & 12 & 0 & 2 \\
\hline Arkansas & 14 & 6 & 0 & 0 & 1 \\
\hline California & 377 & 174 & 61 & 7 & 56 \\
\hline Colorado & 26 & 17 & 12 & 1 & 4 \\
\hline Connecticut & 82 & 13 & 27 & 0 & 5 \\
\hline Delaware & 5 & 3 & 1 & 0 & 0 \\
\hline Florida & 7 & 3 & 5 & 1 & 1 \\
\hline Georgia & 7 & 1 & 13 & 0 & 3 \\
\hline Hawaii & 16 & 15 & 20 & 0 & 3 \\
\hline Idaho & 9 & 4 & 4 & 0 & 0 \\
\hline Illinois & 19 & 8 & 7 & 0 & 2 \\
\hline Indiana & 5 & 3 & 0 & 0 & 1 \\
\hline lowa & 16 & 10 & 9 & 1 & 2 \\
\hline Kansas & 0 & 0 & 0 & 0 & 0 \\
\hline Kentucky & 1 & 0 & 0 & 0 & 1 \\
\hline Louisiana & 2 & 0 & 4 & 0 & 0 \\
\hline Maine & 34 & 15 & 46 & 2 & 3 \\
\hline Maryland & 17 & 3 & 5 & 0 & 9 \\
\hline Massachusetts & 64 & 43 & 17 & 0 & 1 \\
\hline Michigan & 67 & 37 & 35 & 1 & 13 \\
\hline Minnesota & 61 & 24 & 40 & 0 & 10 \\
\hline Mississippi & 3 & 3 & 1 & 0 & 0 \\
\hline Missouri & 7 & 6 & 22 & 0 & 10 \\
\hline Montana & 6 & 2 & 11 & 0 & 1 \\
\hline Nebraska & 3 & 0 & 7 & 1 & 8 \\
\hline Nevada & 0 & 0 & 0 & 0 & 0 \\
\hline New Hampshire & 4 & 4 & 1 & 0 & 0 \\
\hline New Jersey & 57 & 12 & 55 & 0 & 26 \\
\hline New Mexico & 35 & 24 & 30 & 0 & 13 \\
\hline New York & 229 & 91 & 82 & 0 & 33 \\
\hline North Carolina & 8 & 6 & 0 & 0 & 0 \\
\hline North Dakota & 4 & 0 & 0 & 0 & 0 \\
\hline Ohio & 13 & 1 & 5 & 0 & 2 \\
\hline Oklahoma & 0 & 0 & 0 & 0 & 0 \\
\hline Oregon & 30 & 17 & 27 & 4 & 7 \\
\hline Pennsylvania & 84 & 37 & 63 & 21 & 12 \\
\hline Rhode Island & 9 & 1 & 18 & 0 & 1 \\
\hline South Carolina & 0 & 0 & 3 & 0 & 3 \\
\hline South Dakota & 0 & 0 & 0 & 0 & 0 \\
\hline Tennessee & 1 & 1 & 0 & 0 & 3 \\
\hline Texas & 27 & 13 & 15 & 2 & 11 \\
\hline Utah & 2 & 0 & 13 & 0 & 3 \\
\hline Vermont & 11 & 6 & 2 & 0 & 1 \\
\hline Virginia & 14 & 7 & 10 & 0 & 3 \\
\hline Washington & 33 & 11 & 11 & 1 & 4 \\
\hline West Virginia & 0 & 0 & 0 & 0 & 0 \\
\hline Wisconsin & 133 & 105 & 16 & 0 & 3 \\
\hline Totals & 1579 & 739 & 733 & 42 & 276 \\
\hline
\end{tabular}

no victories at the federal level between 1985 and 2005. Pennsylvania saw 21 victories for various state-level offices over this same period - the most of any state. We use the data to create "five-year failure percentages". That is, for any given year (beginning in 1990, since our data only go back to 1985), we look at 
the previous five years of electoral history. Over that five-year span, given the total number of candidates, what percentage of those candidates lost? In further tests, functioning as robustness checks, we also used four-year, sixyear, and ten-year lags, and found extremely similar results in all cases, suggesting that our "five-year" variables use an appropriate time window. These five-year failure percentages are our key independent variables of Percent Local Failure, and Percent State Failure. ${ }^{7}$ We also note that the results found for the 10-year specification help speak to the potential endogeneity problem. Since this regression shows that Green Party campaigns from 10 years ago can affect sabotage rates today, it illustrates that our results are not likely to be driven by a "backlash effect" whereby sabotage increases the failure rates of Green Party candidates. ${ }^{8}$

We also include the Total [Level] Candidates at the local, state, and federal, levels, both in the "inflation" stage and the "main" stage of the regression to help control for the differing strength of the environmental movement from state to state. However, these variables are not a perfect proxy. If ballot access rules are particularly restrictive for third parties in Kansas, for example, then environmentalists might have a strong movement but still not be able to get their candidates on the ballot. Therefore, we include a proxy for the restrictiveness of ballot access laws (Burden 2007; Lem and Dowling 2006): the percentage of the population which would have to sign a petition before a thirdparty candidate could get on the gubernatorial ballot. This is the best available measure of overall ballot access restrictiveness, which we denote as State Signature Percentage. This is important because our argument involves frustration with the failure of the Green Party, not frustration with the absence of the Green Party. It is about the Green Party attracting low support, not about attracting unknown support because they have not yet competed. Thus, it is crucial for us to control for ballot restrictiveness because this stops us conflating how many times the Green Party has tried and failed with how many times the Green Party has been prevented from trying at all. If we observe a stronger effect for the ballot restrictiveness variable than for the "failure percentage" variables, this suggests that the source of frustration comes from the electoral rules, not the electoral results as we hypothesize.

We also include a number of other control variables. In the first stage (the inflation stage) of the regression, we are guided by existing literature on postmaterialism suggesting that richer, more densely populated, and more left-

\footnotetext{
${ }^{7}$ Note that for the states where no candidates ran - Kansas for example - these variables are always zero. This fits our theoretical specification: until the Green Party is perceived to have tried and failed, the likelihood of environmental sabotage is relatively low.

${ }^{8}$ This backlash effect may exist under some circumstances, and further research may be able to test this connection, but for the purposes of our current argument we believe it suffices to show that failure rates from ten years ago, which could not be driven by backlash, can still affect sabotage rates.
} 
wing states, will have the strongest environmental movements (Inglehart 1977). Therefore as well as including the total number of candidates at each level, we also include the natural log of State Area in square miles, the natural log of State Population, the natural log of State Personal Income, and the interest group rating of the State Ideology Score for the state representatives, and the Citizen Ideology Score, both from Berry et al. (1998).

In the second stage (the count stage) of the regression directly predicting the number of environmental sabotage incidents, we again include State Area and State Population, because we expect that larger states and less populated states provide more opportunities for environmental sabotage and make political campaigning harder. We also include State Ideology Score, anticipating that more left-wing states will also be more likely to sanction environmental sabotage. We also include a League of Conservation Voters (LCV) score for that state - namely, the average LCV score of the two US senators for each stateyear. ${ }^{9}$ If Green Party election results are correlated with major party environmentalism, or if radical environmentalism responds more to major parties than Green parties, then this variable will capture that, and so helps control for these alternative explanations. ${ }^{10}$ We also include the natural log of total full-time-equivalent State Law Enforcement Personnel employed by the state police force, which we expect to have a negative effect on the frequency of environmental sabotage. Lastly, to account for potential changes after 9/11 we include a dichotomous variable for the post-2001 period. ${ }^{11}$ We cluster the standard errors by state. Table 2 presents results from these models, using 5 years of electoral history, then 6,4 , and finally 10 years.

Since these coefficients are from a non-linear model, their direction and their statistical significance do not speak directly to $\mathrm{H} 1$. In order to assess whether the coefficients represent a statistically significant effect, we move to a graphical interpretation (Berry, DeMeritt, and Esarey 2010; Brambor, Clark, and Golder 2006; Long and Freese 2006). Figure 1 provides this interpretation, and shows strong support for $\mathrm{H} 1$. In Figure 1, based on the five-year model, we set all the variables to their means and then vary the "percent unsuccessful" simultaneously for state and local campaigns, beginning at $0 \%$ failure and ending at $100 \%$ failure. So, the far left of the graph represents a situation where the Green Party has, over the past five years, run six local campaigns and three state campaigns, and won all of them. The far right of the graph illustrates a situation where the Green Party has run the same set of campaigns, but has lost all of them. Figure 1 shows that the expected rate

\footnotetext{
${ }^{9}$ We include the Senate score since our unit of analysis is the state but obtain similar results if we use House scores instead.

${ }^{10}$ Whilst we acknowledge that the actions of the Democrats and Republicans may affect the Green Party, and radical environmentalists, in more nuanced ways here, we leave these questions for future work. For our purposes in this paper, we focus on the role played by the Green Party, and measure the actions of the other parties only to help us more precisely assess the role played by the Green Party.

${ }^{11}$ We obtain much the same results if we use a year counter rather than dichotomous period indicator.
} 
Table 2. Predicting the number of instances of environmental sabotage (ZINB models).

\begin{tabular}{|c|c|c|c|c|}
\hline & $\begin{array}{c}\text { Four-year } \\
\text { period }\end{array}$ & $\begin{array}{c}\text { Five-year } \\
\text { period }\end{array}$ & $\begin{array}{l}\text { Six-year } \\
\text { period }\end{array}$ & $\begin{array}{c}\text { Ten-year } \\
\text { period }\end{array}$ \\
\hline Total local candidates & $\begin{array}{l}0.019^{* *} \\
(0.008)\end{array}$ & $\begin{array}{l}0.016^{* *} \\
(0.007)\end{array}$ & $\begin{array}{c}0.014^{*} \\
(0.008)\end{array}$ & $\begin{array}{c}0.004 \\
(0.008)\end{array}$ \\
\hline Percent local failure & $\begin{array}{c}0.0004 \\
(0.004)\end{array}$ & $\begin{array}{c}0.003 \\
(0.004)\end{array}$ & $\begin{array}{c}0.003 \\
(0.005)\end{array}$ & $\begin{array}{c}0.0004 \\
(0.006)\end{array}$ \\
\hline Total state candidates & $\begin{array}{c}0.056^{*} \\
(0.033)\end{array}$ & $\begin{array}{c}0.057^{*} \\
(0.033)\end{array}$ & $\begin{array}{l}0.061^{* *} \\
(0.028)\end{array}$ & $\begin{array}{c}0.007 \\
(0.054)\end{array}$ \\
\hline Percent state failures & $\begin{array}{c}0.005 \\
(0.003)\end{array}$ & $\begin{array}{c}0.004 \\
(0.003)\end{array}$ & $\begin{array}{l}0.004 \\
(0.004)\end{array}$ & $\begin{array}{c}0.001 \\
(0.007)\end{array}$ \\
\hline Total federal candidates & $\begin{array}{r}-0.063^{*} \\
(0.036)\end{array}$ & $\begin{array}{r}-0.068 \\
(0.047)\end{array}$ & $\begin{array}{c}-0.072 \\
(0.060)\end{array}$ & $\begin{array}{c}0.031 \\
(0.067)\end{array}$ \\
\hline State area & $\begin{array}{l}0.583^{* *} \\
(0.258)\end{array}$ & $\begin{array}{l}0.592^{* *} \\
(0.231)\end{array}$ & $\begin{array}{l}0.585^{* *} \\
(0.274)\end{array}$ & $\begin{array}{c}-0.004 \\
(0.393)\end{array}$ \\
\hline State population & $\begin{array}{l}-1.562^{* * *} \\
(0.595)\end{array}$ & $\begin{array}{l}-1.561^{* * *} \\
(0.580)\end{array}$ & $\begin{array}{l}-1.553^{* * *} \\
(0.566)\end{array}$ & $\begin{array}{c}-0.007 \\
(0.707)\end{array}$ \\
\hline State law enforcement personnel & $\begin{array}{l}0.780^{* *} \\
(0.395)\end{array}$ & $\begin{array}{l}0.755^{*} \\
(0.390)\end{array}$ & $\begin{array}{l}0.749 * * \\
(0.369)\end{array}$ & $\begin{array}{c}0.006 \\
(0.601)\end{array}$ \\
\hline State ideology score & $\begin{array}{r}-0.002 \\
(0.010)\end{array}$ & $\begin{array}{c}-0.001 \\
(0.010)\end{array}$ & $\begin{array}{c}-0.002 \\
(0.011)\end{array}$ & $\begin{array}{c}0.002 \\
(0.010)\end{array}$ \\
\hline State signature percentage & $\begin{array}{c}1.075 \\
(9.205)\end{array}$ & $\begin{array}{r}-0.964 \\
(9.128)\end{array}$ & $\begin{array}{c}1.268 \\
(9.284)\end{array}$ & $\begin{array}{r}-5.918 \\
(9.371)\end{array}$ \\
\hline LCV senate average & $\begin{array}{c}0.009 \\
(0.006)\end{array}$ & $\begin{array}{r}0.009^{*} \\
(0.006)\end{array}$ & $\begin{array}{l}0.010^{*} \\
(0.005)\end{array}$ & $\begin{array}{c}0.003 \\
(0.010)\end{array}$ \\
\hline Post-2001 & $\begin{array}{c}-0.661^{* * *} \\
(0.219)\end{array}$ & $\begin{array}{c}-0.672^{* * *} \\
(0.210)\end{array}$ & $\begin{array}{c}-0.637^{* * *} \\
(0.200)\end{array}$ & $\begin{array}{r}-0.299 \\
(0.419)\end{array}$ \\
\hline Constant & $\begin{array}{l}11.224 \\
(6.908)\end{array}$ & $\begin{array}{l}11.213^{*} \\
(6.755)\end{array}$ & $\begin{array}{l}11.217 \\
(6.930)\end{array}$ & $\begin{array}{c}-1.141 \\
(6.527)\end{array}$ \\
\hline Alpha & $\begin{array}{c}0.861 \\
(0.501)\end{array}$ & $\begin{array}{c}0.846 \\
(0.522)\end{array}$ & $\begin{array}{l}0.811 \\
(0.524)\end{array}$ & $\begin{array}{c}3.017 \\
(1.520)\end{array}$ \\
\hline $\begin{array}{l}N \\
L L\end{array}$ & $\begin{array}{l}727 \\
-290.035\end{array}$ & $\begin{array}{l}727 \\
-289.304\end{array}$ & $\begin{array}{l}727 \\
-289.067\end{array}$ & $\begin{aligned} & 531 \\
- & 256.438\end{aligned}$ \\
\hline $\begin{array}{l}\text { Chi-squared (12) } \\
\text { Inflate stage }\end{array}$ & $102.59^{* * *}$ & $101.40^{* * *}$ & $101.05^{* * *}$ & $44.50^{* * *}$ \\
\hline State ideology score & $\begin{array}{c}0.011 \\
(0.023)\end{array}$ & $\begin{array}{l}0.014 \\
(0.024)\end{array}$ & $\begin{array}{l}0.013 \\
(0.025)\end{array}$ & $\begin{array}{c}0.043 \\
(0.058)\end{array}$ \\
\hline Citizen ideology score & $\begin{array}{l}-0.052^{* *} \\
(0.025)\end{array}$ & $\begin{array}{l}-0.054^{* *} \\
(0.027)\end{array}$ & $\begin{array}{l}-0.053^{* *} \\
(0.027)\end{array}$ & $\begin{array}{r}-0.020 \\
(0.080)\end{array}$ \\
\hline State personal income & $\begin{array}{r}-3.112^{*} \\
(1.662)\end{array}$ & $\begin{array}{c}-2.981^{*} \\
(1.701)\end{array}$ & $\begin{array}{c}-2.897^{*} \\
(1.687)\end{array}$ & $\begin{array}{l}-5.756 \\
(22.584)\end{array}$ \\
\hline State area & $\begin{array}{c}-1.091 \\
(0.818)\end{array}$ & $\begin{array}{r}-1.116 \\
(0.842)\end{array}$ & $\begin{array}{r}-1.090 \\
(0.889)\end{array}$ & $\begin{array}{l}-5.046 \\
(12.338)\end{array}$ \\
\hline State population & $\begin{array}{l}0.793 \\
(2.191)\end{array}$ & $\begin{array}{l}0.645 \\
(2.251)\end{array}$ & $\begin{array}{c}0.621 \\
(2.234)\end{array}$ & $\begin{array}{c}2.039 \\
(20.842)\end{array}$ \\
\hline Total local candidates & $\begin{array}{l}0.033^{*} \\
(0.018)\end{array}$ & $\begin{array}{l}0.030^{*} \\
(0.015)\end{array}$ & $\begin{array}{l}0.028^{* *} \\
(0.013)\end{array}$ & $\begin{array}{c}0.741 \\
(1.300)\end{array}$ \\
\hline Total state candidates & $\begin{array}{l}0.138^{* * *} \\
(0.061)\end{array}$ & $\begin{array}{l}0.163^{* * *} \\
(0.057)\end{array}$ & $\begin{array}{l}0.169^{* * *} \\
(0.053)\end{array}$ & $\begin{array}{l}-12.125 \\
(19.368)\end{array}$ \\
\hline Total federal candidates & $\begin{array}{r}-0.227 \\
(0.157)\end{array}$ & $\begin{array}{c}-0.289^{* *} \\
(0.126)\end{array}$ & $\begin{array}{c}-0.315^{* *} \\
(0.129)\end{array}$ & $\begin{array}{c}4.592 \\
(7.307)\end{array}$ \\
\hline Constant & $\begin{array}{l}59.619^{* * *} \\
(22.375)\end{array}$ & $\begin{array}{l}59.742^{* * *} \\
(22.733)\end{array}$ & $\begin{array}{l}58.317^{* *} \\
(23.216)\end{array}$ & $\begin{array}{c}127.717 \\
(228.769)\end{array}$ \\
\hline
\end{tabular}

Standard errors clustered by state in parentheses. ${ }^{* * *} p \leq .01,{ }^{* *} p \leq .05,{ }^{*} p \leq .10$.

of sabotage incidents increases almost threefold between these two scenarios, from 0.06 to 0.21 , and also shows $90 \%$ confidence intervals around this effect. 


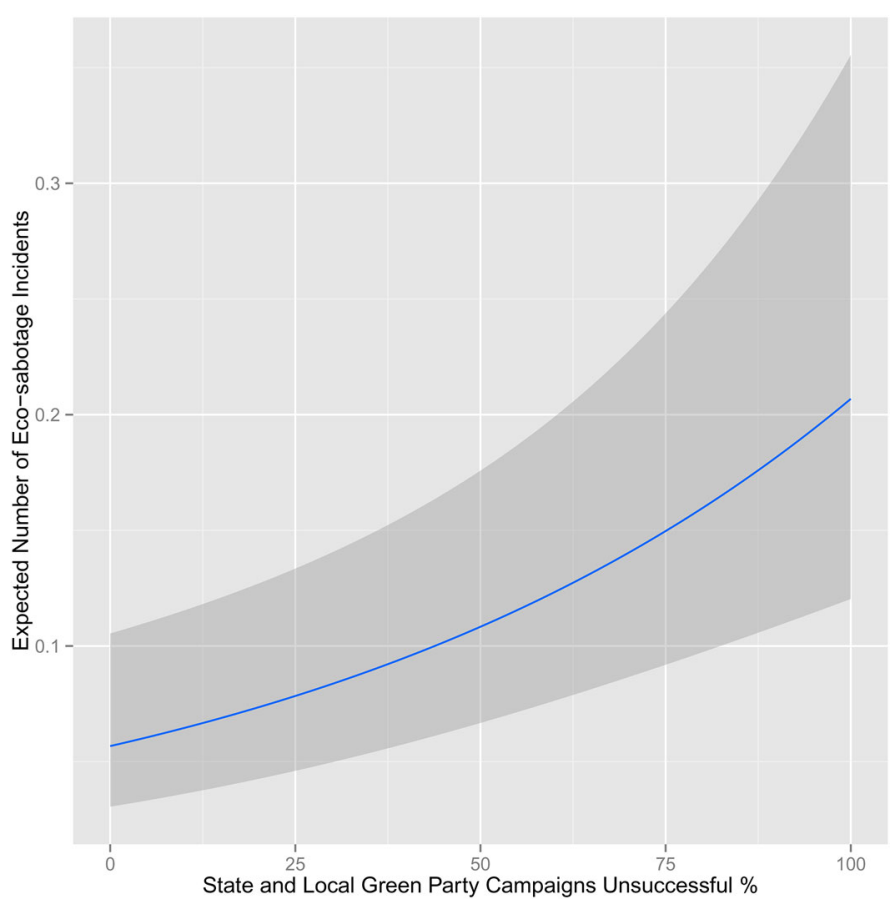

Figure 1. Sabotage becomes more likely if electoral options are consistently unsuccessful.

The substantively meaningful and statistically significant effects provide strong support for $\mathrm{H} 1$. Even when we control for many related factors, such as the overall strength of the environmental movement, the environmental positions of the mainstream parties, as well as ideology of the state and the socio-economic and legal contexts, we still find that Green Party failures are a strong and significant predictor of environmental sabotage. Our argument about substitutability is consistent with the evidence.

However, conventional environmentalists do not just work through the Green Party, as they have also formed interest groups. We use campaign contributions to measure interest group activity. We collect Open Secrets data on Political Action Committee (PAC) contributions to candidates for the US House of Representatives. ${ }^{12}$ We measure the money that came from single-issue ideological PACs representing the environmental movement, such as Friends of the Earth or the LCVs. ${ }^{13}$ In order to calculate "failure rates", we

\footnotetext{
${ }^{12}$ We include contributions in kind, and independent expenditures, and refunded donations are also included (as negative numbers), but negative expenditures are not counted, nor are other kinds of transaction types.

${ }^{13}$ This subset is identified by using the Open Secrets coding scheme for PACs, more details of which can be found on their website.
} 
take this total, and then take only those donations that went to House candidates who ended up losing their race. This gives us the variable Five-Year Environmental PAC Contributions to Losers: a logged, and adjusted for inflation, total amount of money given by environmental PACs to House candidates in the last five years, who ended up losing their election. We acknowledge that contributions which go to losers may not always indicate a failed interest group effort, but we claim that in general frustration is more likely to follow PAC money that was spent on unsuccessful House candidates than on successful House candidates. We also ran robustness checks adding controls for how much environmental PAC money was given to successful candidates, and for the overall amount of donations in each state, and found the same substantive results. Table 3 presents the results from this specification, which is run on a smaller set of observations because donations data are only available from 1989 onwards. We find a positive coefficient on the new donations variable, and the coefficients on failed Green Party campaigns remain of the same approximate magnitude when we control for donations, although with less statistical significance.

In order to interpret these results, Figure 2 reproduces the analysis in Figure 1, except now alongside varying Green Party failure rates from 0 to 100 , we now also vary the logged amount of environmental PAC spending that went to unsuccessful House candidates, from 7 to 11 This range covers the vast majority of the observations in our sample. Figure 2 shows that when we combine all three measures of frustration, we find the same results. Separately, they do not have a significant effect, so we do not find that contributions to unsuccessful campaigns alone leads to more sabotage, but we do find that it reinforces the frustration created by failed Green Party campaigns.

Finally, one potential problem with our argument is that many different types of races are "counted" together. That is, a gubernatorial race is clearly different to a race for state house, but both are classified here as "statelevel" races. Losing a close race for state house might actually trigger a lot more frustration than losing a race for governor that no environmental activists truly expected to win in the first place. Moreover, given that there are almost no occasions of Green Party candidates winning state house races, frustration might be associated not only with losing, but with how much the Green Party lost by. Therefore, we test whether our hypothesis still holds when we only look at one relatively comparable office, and when we conceptualize failure not as failing to win the seat, but instead as failing to win a high percentage of the vote.

Table 4 includes the same specification from Table 2, but now with only one "total number of candidates" variable, which refers to state house races. Our "failure percentage" variables are replaced by taking the vote percentage the Green Party won in each of these races, and calculate an average vote percentage for each year. These become the components 
Table 3. Predicting the number of instances of environmental sabotage, including donations (ZINB models).

\begin{tabular}{|c|c|}
\hline & Five-year period \\
\hline Total local candidates & $\begin{array}{l}0.014^{* *} \\
(0.006)\end{array}$ \\
\hline Percent local failure & $\begin{array}{l}0.007 \\
(0.004)\end{array}$ \\
\hline Total state candidates & $\begin{array}{l}0.062^{* *} \\
(0.028)\end{array}$ \\
\hline Percent state failures & $\begin{array}{l}0.003 \\
(0.004)\end{array}$ \\
\hline Total federal candidates & $\begin{array}{c}-0.058 \\
(0.045)\end{array}$ \\
\hline State area & $\begin{array}{c}0.246 \\
(0.361)\end{array}$ \\
\hline State population & $\begin{array}{c}-1.375^{* *} \\
(0.689)\end{array}$ \\
\hline State law enforcement personnel & $\begin{array}{c}0.552 \\
(0.584)\end{array}$ \\
\hline State ideology score & $\begin{array}{c}0.013 \\
(0.010)\end{array}$ \\
\hline State signature percentage & $\begin{array}{c}-3.178 \\
(9.554)\end{array}$ \\
\hline Post-2001 & $\begin{array}{c}-0.627^{* *} \\
(0.314)\end{array}$ \\
\hline LCV senate score & $\begin{array}{l}0.007 \\
(0.007)\end{array}$ \\
\hline Environmental PAC contributions to losers & $\begin{array}{l}0.106 \\
(0.113)\end{array}$ \\
\hline Constant & $\begin{array}{l}11.895^{* *} \\
(5.766)\end{array}$ \\
\hline Alpha & $\begin{array}{c}0.407 \\
(0.722)\end{array}$ \\
\hline$N$ & 579 \\
\hline LL & -240.177 \\
\hline $\begin{array}{l}\text { Chi-squared (14) } \\
\text { Inflate stage }\end{array}$ & $120.60^{* * *}$ \\
\hline State ideology score & $\begin{array}{l}0.026 \\
(0.024)\end{array}$ \\
\hline Citizen ideology score & $\begin{array}{c}-0.064^{* *} \\
(0.030)\end{array}$ \\
\hline State personal income & $\begin{array}{c}-1.516 \\
(2.072)\end{array}$ \\
\hline State area & $\begin{array}{r}-1.280 \\
(0.852)\end{array}$ \\
\hline State population & $\begin{array}{c}-1.013 \\
(2.935)\end{array}$ \\
\hline Total local candidates & $\begin{array}{c}0.031 \\
(0.020)\end{array}$ \\
\hline Total state candidates & $\begin{array}{l}0.160^{* *} \\
(0.063)\end{array}$ \\
\hline Total federal candidates & $\begin{array}{c}-0.274^{* *} \\
(0.136)\end{array}$ \\
\hline Constant & $\begin{array}{l}59.273^{* *} \\
(26.306)\end{array}$ \\
\hline
\end{tabular}

Standard errors clustered by state in parentheses. ${ }^{* * *} p \leq .01,{ }^{* *} p \leq .05,{ }^{*} p \leq .10$. 


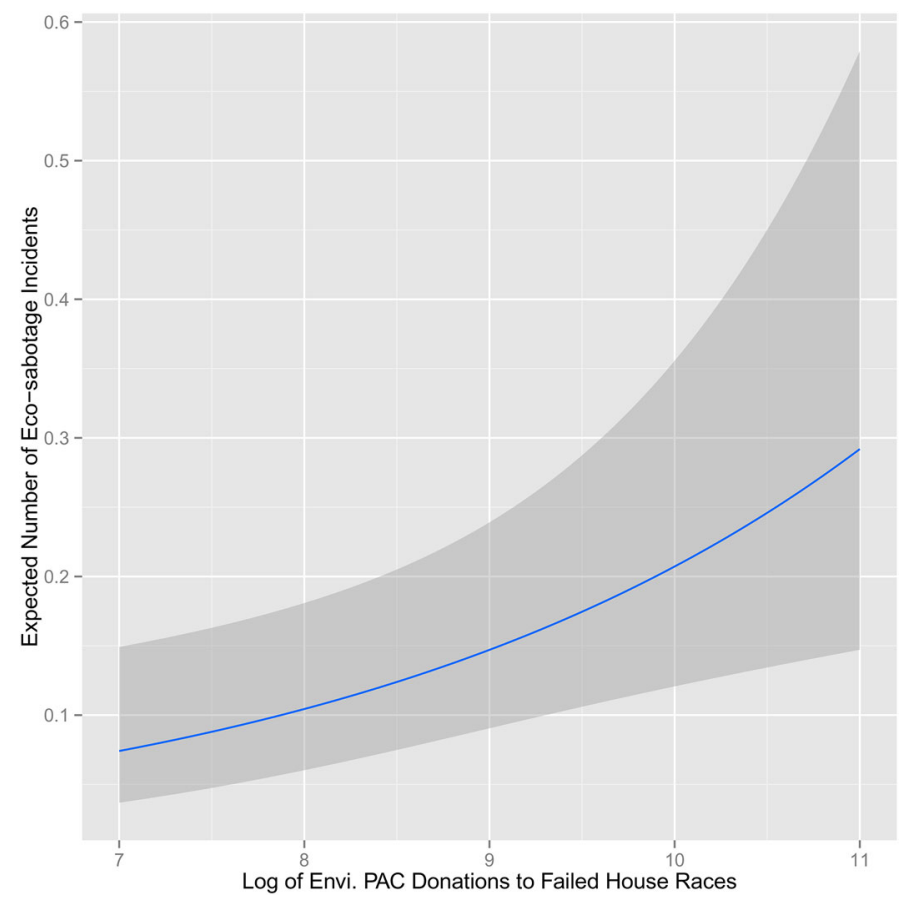

Figure 2. Environmental PAC donations to failed house candidates also are associated with eventual increases in environmental sabotage.

for a five-year average vote percentage variable, which is the key variable for testing our hypothesis. As the five-year electoral history of the Green Party is filled with higher average vote percentages in state house races, we expect that environmental sabotage becomes less likely. The final control variable we add here is the most recent Green Party vote percentage in the gubernatorial election, State Gubernatorial Vote Percentage, to help account for at least some portion of the other electoral performances of the Green Party.

The results in Table 4 corroborate the story told by Table 2 and Figures 1 and 2. Figure 3 indicates that better performances in State House races are very weakly associated with a slight decline in the expected number of instances of environmental sabotage. Two things are worth noting about these results. First, there is a positive association at the lowest levels of the independent variable, suggesting that frustration and substitution do not come into play unless the Green Party has at least mounted a meaningful campaign winning a vote share in the double digits. Second, although these results reinforce the logic of our hypothesis, they are not statistically significant, and their substantive effect is much smaller - the model is generally sensitive to changes in specification. We believe that this is a natural result of narrowing our focus down to a single race: Figures 1 and 2 give a more accurate and holistic portrayal. 
Table 4. Predicting the number of instances of environmental sabotage (ZINB models) only using state house race information.

\begin{tabular}{|c|c|}
\hline & Five-year period \\
\hline Five-year total state house candidates & $\begin{array}{c}-0.021 \\
(0.021)\end{array}$ \\
\hline Five-year state house races won & $\begin{array}{c}1.152^{* *} \\
(0.556)\end{array}$ \\
\hline Five-year average state house vote percentage & $\begin{array}{r}-0.015 \\
(0.016)\end{array}$ \\
\hline Gubernatorial vote percentage & $\begin{array}{l}0.614^{* *} \\
(0.291)\end{array}$ \\
\hline State area & $\begin{array}{c}0.567^{* *} \\
(0.256)\end{array}$ \\
\hline State population & $\begin{array}{c}-1.537^{* *} \\
(0.709)\end{array}$ \\
\hline State law enforcement personnel & $\begin{array}{l}1.129^{* *} \\
(0.477)\end{array}$ \\
\hline State ideology score & $\begin{array}{c}0.005 \\
(0.008)\end{array}$ \\
\hline State signature percentage & $\begin{array}{r}-6.089 \\
(9.345)\end{array}$ \\
\hline LCV senate score & $\begin{array}{l}0.014^{* *} \\
(0.006)\end{array}$ \\
\hline Post-2001 & $\begin{array}{c}-0.079 \\
(0.268)\end{array}$ \\
\hline Constant & $\begin{array}{l}7.875 \\
(6.389)\end{array}$ \\
\hline Alpha & $\begin{array}{l}1.341 \\
(0.486)\end{array}$ \\
\hline$N$ & 727 \\
\hline$L L$ & -266.667 \\
\hline $\begin{array}{l}\text { Chi-squared (11) } \\
\text { Inflate stage }\end{array}$ & . \\
\hline State ideology score & $\begin{array}{l}0.055 \\
(0.035)\end{array}$ \\
\hline Citizen ideology score & $\begin{array}{r}-0.072 \\
(0.049)\end{array}$ \\
\hline State personal income & $\begin{array}{r}-0.005 \\
(2.175)\end{array}$ \\
\hline State area & $\begin{array}{c}-2.203^{* *} \\
(0.914)\end{array}$ \\
\hline State population & $\begin{array}{l}-3.882^{* * *} \\
(3.809)\end{array}$ \\
\hline Gubernatorial vote percentage & $\begin{array}{l}2.959^{* *} \\
(1.231)\end{array}$ \\
\hline Five-year average state house vote percentage & $\begin{array}{c}-0.738^{* *} \\
(0.319)\end{array}$ \\
\hline Constant & $\begin{array}{l}83.722^{* *} \\
(33.429)\end{array}$ \\
\hline
\end{tabular}

Standard errors clustered by state in parentheses. ${ }^{* * *} p \leq .01,{ }^{* *} p \leq .05,{ }^{*} p \leq .10$.

These results, taken together, all point towards the same conclusion. Although the Green Party is philosophically opposed to violent direct action, it nonetheless plays an unconscious role in the process. Environmental sabotage is unlikely in states that have successful Green Parties. Even controlling for the overall "strength" of the Green Party in terms of the number of races they enter, and controlling for whether the mainstream parties are 


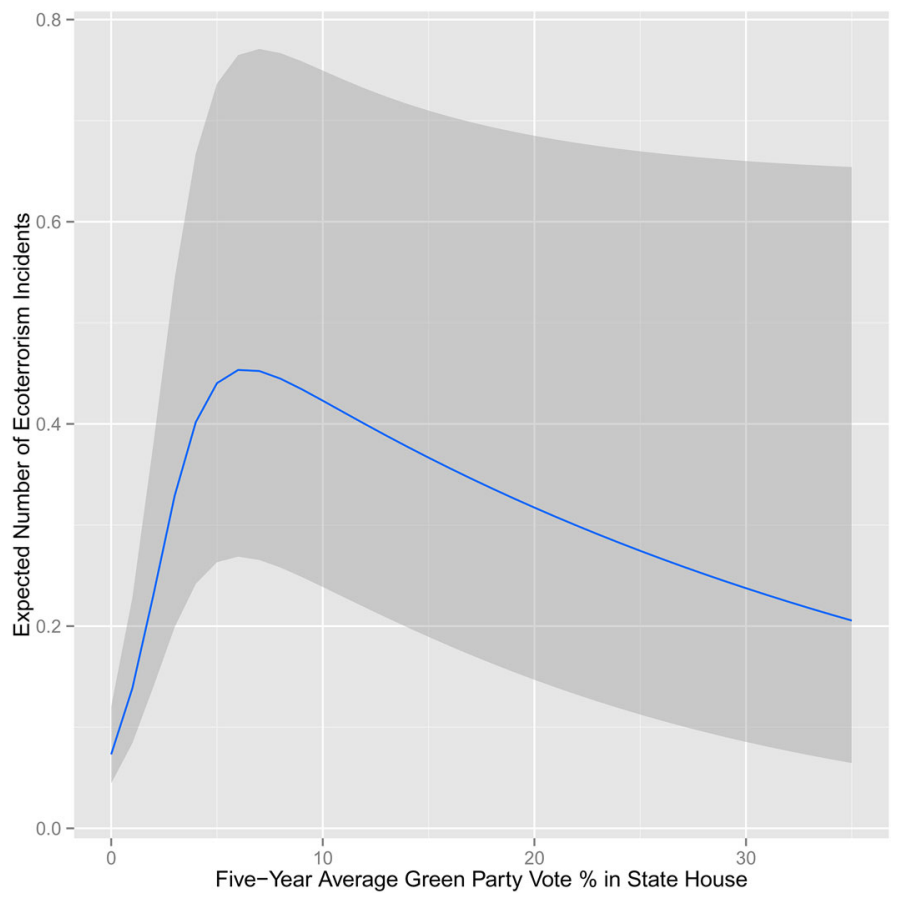

Figure 3. High average vote percentages for green party candidates in state house races are associated with fewer environmental sabotage incidents.

adopting environmental positions, sabotage is still positively correlated with the failure rate of local Green party races. We also show that this correlation emerges again - and is even reinforced - when we control for the failure rates of other political expressions of environmentalism, such as PAC contributions. Finally, we look at an alternative definition of failure. That is, we look, not just at whether the Green Party won or lost, but also at whether they won a large or small share of the vote. Once again we find - albeit with less statistical significance - a positive correlation between a history of Green Party failure, and the frequency of environmental sabotage in the future. We argue that this is due to the potential support network of environmental saboteurs using Green Party success as a barometer of whether they can achieve their goals inside the system or whether instead they must turn to the riskier option of violent direct action.

\section{Conclusion}

We have explained how environmental sabotage becomes more likely if mainstream tactics prove ineffective. Environmental sabotage is often considered separately from these other tactics, because of the dramatic difference 
in legality. However, we argue that these various political expressions of environmentalism are best considered together (Doherty 2002; Farrer 2014; HirschHoefler and Mudde 2014; List 1993). Although mainstream and radical activists often seem to want nothing to do with each other (Klein 2014; Monbiot and Porritt 2000; Pellow 2014; White 2016), we show evidence that the two "opposite wings" of the movement are connected (Hutter and Vliegenthart 2016). There are measurable and systematic patterns of substitution between environmental sabotage and other forms of environmental activism. However, to reiterate, we do not suggest that this connection is such that any environmental activist moves entirely from mainstream tactics to radical tactics simply as a result of the failure of the former. Rather, many individuals make slight changes to their behavior. Those individuals who consider aiding environmental sabotage, as a last resort, might be swayed against it if other forms of environmental activism appear less risky and at least as instrumentally effective.

We draw a number of tentative implications from this study. First, this suggests that even groups committed to direct action are nevertheless caught in the gravitational pull of the state. Although environmental saboteurs may think of themselves as "outside the system", if their type of radical activism is prompted by the failure of mainstream activism, then it is a reaction to the system, and therefore still intimately connected to that system. Second, because social movements unite diverse individuals under the banner of a united cause during times of optimistic challenge (Tarrow 1994), success within legitimate avenues might satisfy the movement. But, when these avenues provide insufficient opportunities for redress and change, as represented by long-term electoral failure, then splits between radical and mainstream activists are fostered and consequently, some activists united under the movement's shared goal(s) turn to the politics of bullets rather than ballots (della Porta 1995; McLauchlin and Pearlman 2012; Tarrow 1994). Thus, the evidence here suggests that having a two-party system that effectively locks minor parties out of the representation process can push extremists towards violence (Aksoy and Carter 2014).

Third, our argument has extensions beyond electoral institutions. If the media refuse to cover an extremist party, or if major party insiders conspire to block the nomination of a radical candidate, then they are effectively locking those activists out of the democratic process, as surely as does the two-party system. Are such actions effective in the long run? Or are they counterproductive? Our evidence suggests that each time a radical group is ostracized, a degree of frustration builds. If a long enough history accumulates of such ostracism, some individual activists in these radical groups may turn to violence. Rather than extremist campaigns contributing to violence through their rhetoric, they may detract from violence by acting as a substitute (Green, McFalls, and Smith 2001). Our example comes from a unique ideology 
with a commitment to not harming living things, it suggests a very preliminary counter-argument. Though it would be unwise to generalize from our one example, it represents another data point in ongoing efforts to improve our understanding of the processes leading to violent politics (Green, McFalls, and Smith 2001; Hutter and Vliegenthart 2016; McAdam, McCarthy, and Zald 1996; McAdam, Tarrow, and Tilly 2001; Tarrow 1989) and can better adapt political systems to reflect public sentiment and avoid violence.

\section{Disclosure statement}

No potential conflict of interest was reported by the authors.

\section{Notes on contributors}

Ben Farrer is Assistant Professor of Environmental Studies at Knox College. His research and teaching interests focus on parties and interest groups, environmental politics, and methodology.

Graig Klein is a doctoral candidate in Political Science at Binghamton University specializing in International Relations, American Politics and Research Methodology.

\section{ORCiD}

Benjamin Farrer (D) http://orcid.org/0000-0002-5889-5498

\section{References}

Abrahms, Max. 2008. "What Terrorists Really Want: Terrorist Motives and Counterterrorism Strategy." International Security 32 (4): 78-105.

Acemoglu, Daron, and James Robinson. 2006. Economic Origins of Dictatorship and Democracy. New York: Cambridge University Press.

Acemoglu, Daron, and James Robinson. 2008. "Persistence of Power, Elites, and Institutions." American Economic Review 98: 267-93.

Aksoy, Deniz, and David B. Carter. 2014. "Electoral Institutions and the Emergence of Terrorist Groups." British Journal of Political Science 44 (1): 181-204.

Amster, Randall. 2006. "Perspectives on Ecoterrorism: Catalysts, Conflations, and Casualties." Contemporary Justice Review 9 (3): 287-301.

Berry, William D., Jacqueline H. R. DeMeritt, and Justin Esarey. 2010. "Testing for Interaction in Binary Logit and Probit Models: Is a Product Term Essential?" American Journal of Political Science 54 (1): 248-266.

Berry, William D., Evan T. Ringquist, Richard C. Fording, and Russell L. Hanson. 1998. "Measuring Citizen and Government Ideology in the American States, 1960-93." American Journal of Political Science 42 (1): 327-348.

Bishara, Dina. 2015. "The Politics of Ignoring: Protest Dynamics in Late Mubarak Egypt." Perspectives on Politics 13 (4): 958-975.

Blazak, Randy. 2001. "White Boys to Terrorist Men: Target Recruitment of Nazi Skinheads." American Behavioral Scientist 44: 982-1000. 
Borum, Randy. 2011. "Radicalization into Violence Extremism I: A Review of Social Science Theories." Journal of Strategic Studies 4 (4): 7-36.

Brambor, Thomas, William Clark, and Matt Golder. 2006. "Understanding Interaction Models: Improving Empirical Analyses." Political Analysis 14 (1): 63-82.

Burden, Barry. 2007. "Ballot Regulations and Multiparty Politics in the States." PS: Political Science and Politics. 40 (4): 669-673.

Cameron, A. Colin, and Pravin K. Trivedi. 1998. Regression Analysis of Count Data. Cambridge: Cambridge University Press.

Deshpande, Nick, and Howard Ernst. 2012. Countering Eco-Terrorism in the United States: The Case of "Operation Backfire". College Park, MD: National Consortium for the Study of Terrorism and Responses to Terrorism.

Doherty, Brian. 2002. Ideas and Actions in the Green Movement. New York: Routledge.

Dryzek, John S., David Downes, Christian Hunold, David Schlosberg, and Hans-Kristian Hernes. 2003. Green States and Social Movements. Oxford: Oxford University Press.

Dunnning, Thad. 2011. "Fighting and Voting: Violent Conflict and Electoral Politics." Journal of Conflict Resolution 55 (3): 327-339.

Enders, Walter, and Todd Sandler. 1993. "The Effectiveness of Antiterrorism Policies: A Vector-Autoregression-Intervention Analysis." American Political Science Review 87 (4): 829-844.

Farrer, Benjamin. 2014. "A Theory of Organizational Choice: Parties and Interest Groups as Substitutable Influence Mechanisms." Party Politics 20 (4): 632-645.

Farrer, Benjamin. 2016. "An Experiment Assessing How Different Forms of Utility Inform the Choices of Environmental Activists." Environment and Behavior 48 (7): 885-904.

Fox Piven, Frances, and Richard A. Cloward. 1971. Regulating the Poor: The Functions of Public Welfare. New York, NY: Pantheon Books.

Gamson, William. 1975. The Strategy of Social Protest. Homewood, IL: The Dorsey Press.

Green, Donald, Jonathan Krasno, Costas Panagopoulos, Benjamin Farrer, and Michael Schwam-Baird. 2015. "Encouraging Small Donor Contributions: Field Experiments Testing the Effects of Nonpartisan Messages." Journal of Experimental Political Science 2 (2): 183-191.

Green, Donald, Laurence H. McFalls, and Jennifer K. Smith. 2001. "Hate Crime: An Emergent Research Agenda." Annual Review of Sociology 27 (1): 479-504.

Gruenewald, Jeff, Kayla Allison-Gruenewald, and Brent R. Klein. 2015. "Assessing the Attractiveness and Vulnerability of Eco-Terrorism Targets: A Situational Crime Prevention Approach." Studies in Conflict \& Terrorism 38 (6): 433-455.

Hawkins, Howie, ed. 2006. Independent Politics: The Green Party Strategy Debate. Chicago: Haymarket Books.

Hirsch-Hoefler, Sivan, and Cas Mudde. 2014. "'Ecoterrorism': Terrorist Threat or Political Ploy?" Studies in Conflict \& Terrorism 37 (7): 586-603.

Horgan, John. 2005. The Psychology of Terrorism. New York: Routledge.

Hutter, Swen, and Rens Vliegenthart. 2016. "Who Responds to Protest? Protest Politics and Party Responsiveness in Western Europe." Party Politics doi:1354068816657375.

Inglehart, R. H. 1977. The Silent Revolution: Changing Values and Political Styles among Western Publics. Princeton, NJ: Princeton University Press.

Joosse, Paul. 2007. "Leaderless Resistance and Ideological Inclusion: The Case of the Earth Liberation Front." Terrorism and Political Violence 19 (3): 351-368.

Karasick, Paul J. 2009. "Curb Your Ecoterrorism." William and Mary Environmental Law and Policy Review 33 (2): 581-603.

Klein, Naomi. 2014. This Changes Everything. New York: Simon \& Schuster. 
Kollman, Ken. 1997. "Inviting Friends to Lobby." The American Journal of Political Science 41 (2): 519-544.

Koopmans, R. 1996. "Explaining the Rise of Racist and Extreme Right Violence in Western Europe: Grievances and Opportunities?" European Journal of Political Research 30 (2): 185-216.

Kraft, Michael E. 2011. Environmental Policy and Politics. Boston, MA: Longman.

Kuipers, Dean. 2009. Operation Bite Back: Ron Coronado's War To Save The American Wilderness. New York: Bloomsbury.

Lake, David. 2002. "Rational Extremism: Understanding Terrorism in the Twenty-First Century." Dialogue 101 (1): 15-29.

Lawson, Kay, and Peter H. Merkl, eds. 1988. When Parties Fail: Emerging Alternative Organizations. Princeton, NJ: Princeton University Press.

Leader, Stefan H., and Peter Probst. 2003. "The Earth Liberation Front and Environmental Terrorism." Terrorism and Political Violence 15 (4): 37-58.

Lees, Charles. 2000. The Red-Green Coalition in Germany. Manchester: Manchester University Press.

Lem, Steve, and Conor Dowling. 2006. "Picking Their Spots: Minor Party Candidates in Gubernatorial Elections." Public Opinion Quarterly. 59 (3): 471-480.

List, Peter C., ed. 1993. Radical Environmentalism: Philosophy and Tactics. Belmont: Wadsworth.

Long, J. Scott and Jeremy Freese. 2006. Regression Models for Categorical Dependent Variables Using Stata. 2nd ed. College Station, TX: StataCorp LP.

Lucas, Caroline. 2015. Honourable Friends? London: Portobello Books.

Marris, Emma. 2006. "In The Name of Nature." Nature 443 (5): 498-501.

McAdam, Doug, John D. McCarthy, and Mayer N. Zald, eds. 1996. Comparative Perspectives on Social Movements. Cambridge: Cambridge University Press.

McAdam, Doug, Sidney Tarrow, and Charles Tilly. 2001. Dynamics of Contention. Cambridge: Cambridge University Press.

McAllister, Ian. 2004. "The Armalite and the Ballot Box: Sinn Fein's Electoral Strategy in Northern Ireland." Electoral Studies 23 (1): 123-142.

McCarthy, John D., and Mayer N. Zald. 1977. "Resource Mobilization and Social Movements: A Partial Theory." The American Journal of Sociology 82 (6): 1212-1241.

McLauchlin, Theodore, and Wendy Pearlman. 2012. "Out-Group Conflict, In-Group Unity? Exploring the Effect of Repression on Intramovement Cooperation." Journal of Conflict Resolution 56 (1): 41-66.

Meguid, Bonnie. 2008. Party Competition Between Unequals. Cambridge, UK: Cambridge University Press.

Meyer, Margit, and John Ely, eds. 1998. The German Greens: Paradox Between Movement and Party. Philadelphia, PA: Temple University Press.

Monbiot, G., and J. Porritt. 2000. "Does Working with Business Compromise the Environmentalist?" The Ecologist 30: 20-23.

National Consortium for the Study of Terrorism and Responses to Terrorism (START). 2013. "Global Terrorism Database [Data file]." http://www.start.umd.edu/gtd.

O'Neill, Michael. 1997. Green Parties and Political Change in Contemporary Europe. Aldershot: Ashgate Publishing.

Pellow, David Naguib. 2014. Total Liberation: The Power and Promise of Animal Rights and the Radical Earth Movement. Minneapolis: University of Minnesota Press.

della Porta, Donatella. 1995. Social Movements, Political Violence, and the State. Cambridge: Cambridge University Press. 
Rootes, Christopher. 2013. "Mobilising for the Environment: Parties, NGOs, and Movements." Environmental Politics 22 (5): 701-705.

Scarce, Rik. 2006. Eco-Warriors: Understanding the Radical Environmental Movement. 2nd ed. Walnut Creek, CA: Left Coast Press.

Silke, Andrew. 2008. "Holy Warriors: Exploring the Psychological Processes of Jihadi Radicalization." European Journal of Criminology 5 (1): 99-123.

Tarrow, Sidney. 1989. Struggle, Politics, and Reform: Collective Action, Social Movements, and Cycles of Protest. Cornell, NY: Center for International Studies, Cornell University.

Tarrow, Sidney. 1994. Power in Movement. Cambridge: Cambridge University Press.

Tilly, Charles. 2004. "Terror, Terrorism, Terrorists." Sociological Theory 22 (1): 5-13.

Van der Heijden, H. A. 1999. "Environmental Movements, Ecological Modernisation and Political Opportunity Structures." Environmental Politics 8 (1): 199-221.

Vanderheiden, Steven. 2005. "Eco-Terrorism or Justified Resistance? Radical Environmentalism and the 'War on Terror'." Politics \& Society 33 (3): 425-447.

Varriale Carson, Jennifer, Gary Lafree, and Laura Dugan. 2012. "Terrorist and NonTerrorist Criminal Attacks by Radical Environmental and Animal Rights Groups in the United States, 1970-2007." Terrorism and Political Violence 24 (2): 295-319.

Weinberg, Leonard, Ami Pedazhur, and Arie Perliger. 2009. Political Parties and Terrorist Groups. 2nd ed. London: Routledge.

Weyler, Rex. 2004. Greenpeace: How a Group of Ecologists, Journalists, and Visionaries Changed the World. Vancouver: Rodale.

White, Micah. 2016. The End of Protest. Knopf: Toronto. 